\title{
Physiology Practicals by Health Science Students in COVID-19 Pandemic
}

\author{
Yashoda Ravindra Kattimani*, Mahantayya Veerabhadrayya Math, Rita Manoj Khadkikar
}

\section{Yashoda Ravindra Kattimani*, Mahantayya Veerabhadrayya Math, Rita Manoj Khadkikar}

\author{
Department of Physiology, MGM \\ Medical College, Kamothe, \\ Navi Mumbai, Maharashtra, INDIA. \\ *Correspondence \\ Dr. Yashoda R Kattimani \\ Associate Professor, Department of \\ Physiology, MGM Medical College, \\ Kamothe, Navi Mumbai-410209, \\ Maharashtra, INDIA. \\ Phone: +91-9969042925 \\ Email: yashoda.ravindra@yahoo. \\ com \\ History \\ - Submission Date: 18-05-2021; \\ - Review completed: 14-06-2021 \\ - Accepted Date: 26-06-2021.
}

DOI : 10.5530/ijcep.2021.8.2.23

Article Available online

http://www.ijcep.org

\section{Copyright}

(C) 2021 Phcog.Net. This is an openaccess article distributed under the terms of the Creative Commons Attribution 4.0 International license.
Sir,

The coronavirus disease (COVID-19) is a pandemic. This has spread to many countries in the world, The hACE2 is an essential gene and the entire human population is susceptible to SAR-CoV-2 infection. ${ }^{[1]}$ The Government of India has taken actions to control the spread of COVID-19. The central and state governments are taking several measures for the control of spread of Infection.

An easy way to decrease SARS-CoV-2 infection rates is to avoid virus exposure. Necessary preventive measures, such as wearing a mask, regular hand washing, avoiding direct contact with infected persons and social distancing should be practiced. ${ }^{[1]}$ Corona virus infectious disease (COVID-19) has changed everyday life globally, with nearly 220 countries and territories experiencing its devastating impact. Countries or states across the globe have enacted rules designed to limit the spread of the virus by requiring inhabitants to stay home and adhere to social distancing; and markedly limiting face-to-face activities.

The Board of the General Assembly of the International Union of Physiological Sciences (BGA/IUPS) reached out to member societies to gather information on the impact of the COVID-19 pandemic on their society operations and the activities of their members. Twenty five physiological societies representing Africa, the Americas, Asia (including India), Europe/European Union, the Mideast, and Oceania have participated in this. The Physiological Society also convened a meeting of 650 physiologists to discuss problems and share advice on returning to laboratory research safely during the pandemic. ${ }^{[2]}$

Hannah and colleagues have observed that College campuses are at risk of becoming COVID-19 super spreaders for their entire county. ${ }^{[3]}$ Young people play vital role in stopping spread of COVID-19. ${ }^{[4]}$

Saliva can transmit Covid-19 Infections during mouth pipetting. Saliva is a good alternative to nasopharyngeal / oropharyngeal swabs for COVID-19 diagnosis and monitoring. ${ }^{[5}$

Salivary glands have ACE 2 receptors for Covid-19 virus. Alves and colleagues have noted that infection by COVID-19 alters body homeostasis, affecting the renin-angiotensin-aldosterone system (RAAS) This is due to an interaction with the angiotensinconverting agent enzyme 2 (ACE2) in our body and this facilitates COVID-19 in host cells and thereby, harms the homeostasis. In addition to affecting the respiratory system, the virus also acts on the nervous, cardiac, metabolic, and renal systems, demonstrating its different interactions with the human body. ${ }^{[6]}$

Each year thousands of students are performing haematology practicals in their first year in Medical, Dental, pharmacy and Allied Health Science courses. ${ }^{[4]}$ Mouth pipetting is used in haematology practicals in India and other developing countries. Math and colleagues have shown that a rubber bulb (used as a pipetting aid) to draw blood for hemoglobin pipette (to do hemoglobin estimation, RBC count, WBC count and Platelet count) will be of help in avoiding mouth pipetting while performing hematology practical's. ${ }^{[7]}$ In the Covid-19 pandemic Social distancing, wearing mask, hand washing and avoiding direct contact with infected patients will help in reducing spread of infection. In addition to the above measures touching of chin and the areas around the mouth, nose and eyes will help in fast transmission of Covid-19 in individuals. Increased frequency of face touching behavior in the public was seen in Australian medical students in their first year at university. Face touching is a common in and this may help in COVID-19 transmission in the absence of hand hygiene. ${ }^{[8,9]}$ Tissue paper use can decrease the frequency of touching the face, nose and mouth. ${ }^{[10]}$

\section{REFERENCES}

1. Wang C, Wang Z, Wang G, Lau JYN, Zhang K, Li W. COVID-19 in early 2021: current status and looking forward. Signal Transduct Target Ther. 2021;6(1):114 doi: 10.1038/s41392-021-00527-1, PMID 33686059.

2. Barman Vice Chair Board Of The General Assembly SM Csernoch Member Board Of The General Assembly L, Sengupta Chair Board Of The General Assembly J. Physolocal Societies Across the Globe Unite in an Effort to Handle the COVID-19 Pandemic. Physiology (Bethesda). 2021;36(2):62-70. doi: 10.1152/physiol.00001.2021 PMID 33595387

3. Lu H, Weintz C, Pace J, Indana D, Linka K, Kuhl E. Are college campuses superspreaders? A data-driven modeling study. Comput Methods Biomech Biomed Engin. 2021:1-11. doi: 10.1080/10255842.2020.1869221, PMID 33439055.

4. Jenco M. Young people play vital role in stopping spread of COVID-19.

5. Sapkota D, Søland TM, Galtung HK, Sand LP, Giannecchini S, To KKW, Mendes-Correa MC, Giglio D, Hasséus B, Braz-Silva PH. COVID-19 salivary signature: diagnostic and research opportunities. J Clin Pathol 2020:0:1.6. do: 10.1136/jclinpath-2020-206834, PMID 32769214.

Cite this article: Kattimani YR, Math MV, Khadkikar RM. Physiology Practicals by Health Science Students in COVID-19 Pandemic. Int J Clin Exp Physiol. 2021;8(2):104-5 
6. Alves N, Carrazoni GS, Soares CB, Rosa ACSD, Soares NM, Mello-Carpes PB. Relating human physiology content to COVID-19: a strategy to keep students in touch with physiology in times of social distance due to pandemic. Adv Physiol Educ. 2021;45(1):129-33. doi: 10.1152/advan.00214.2020, PMID 33661051.

7. KattimaniYR, Khadkikar RM, Inamdar RS, Math MV, Padhye M, Gawali SR, Rai M. A Safe and Easy Method for Hematology Practicals. MGM Journal of Medical Sciences. 2019;6(1):48-50. doi: 10.5005/jp-journals-10036-1230.
8. Kwok YLA, Gralton J, McLaws ML. Face touching: a frequent habit that has implications for hand hygiene. Am J Infect Control. 2015;43(2):112-14. doi: 10.1016/j.ajic.2014.10.015, PMID 25637115.

9. Shiraly R, Shayan Z, McLaws ML. Face touching in the time of COVID-19 in Shiraz, Iran. Am J Infect Control. 2020;48(12):1559-61. doi: 10.1016/j. ajic.2020.08.009, PMID 32798630.

10. How to stop touching your face. New York times published. James Nieves. The New York Times [updated Mar 9, 2020]: March 5, 2020.

Cite this article: Kattimani YR, Math MV, Khadkikar RM. Physiology Practicals by Health Science Students in COVID-19 Pandemic. Int J Clin Exp Physiol. 2021;8(2):104-5. 